\title{
Description of the Verbal System of Albanian Language in the " Grammar of the Albanian Language" (1882) of Konstandin Kristoforidhi
}

\author{
Dr. Manola Kaçi (Myrta)
}

"Aleksandër Moisiu” University, Durrës; manola.myrta@yahoo.com

\section{Doi:10.5901/ajis.2015.v4n3s1p421}

One of the most significant works of Kristoforidhi is the "Grammar of Albanian language". The author published this work in Greek ("Gramatiqi'tis Alvaniqi's Glo'sis), in 1882, in Istanbul. Albanian grammatology actually had very good traditions in this respect, but If we would refer to the linguist Shaban Demiraj, following the grammar of De Rada, the grammar of Kristoforidhi is the second grammar of the Albanian language, written and published by an Albanian, and the best work of this kind written hitherto by foreign scholars (Demiraj, 2002 p. 42).

In his Albanian Grammar text, Kristoforidhi describes in detail the Albanian morphology. Given the intention to not draft a simply educational grammar and to raise the Albanian language at the same scientific level as the most advanced languages in Europe, the Grammar of Kristoforidhi has the appearance of a linguistic manual in which the morphological structures of Albanian Language appear and is supported by numerous linguistic facts and diverse examples provided in both Albanian dialects (Karapinjalli, Stringa, 2002, p. 213).

Although it is generally a descriptive grammar, it is designed on sound theoretical grounds that permeate it from the beginning of the treatment until the end. This linguistic theory is revealed in the systematic submission of all factual language material, including from time to time even the numerous explanatory notes of the author himself.

In his work "Grammar of Albanian language", Kristoforidhi distinguishes these lexical and grammatical categories: junction, name, surname, numerator, pronoun, verb, adverb, preposition, conjunction and exclamation; the verb chapter is ranked as the most important one of the whole study. A full presentation of Albanian verbal system is done in this chapter, pointing out commonalities and specificities of dialects and forms of Albanian taken into consideration. There are many tables regarding the conjugation of verbs including separate conjugation of verbs "to have" (kam) and "to be" (jam).

Kristoforidhi aimed the complete description of the verbal system of Albanian language, but according to the linguist Shaban Demiraj: "Kristoforidhi has done an even greater work, though not always written" (Demiraj, 2002 p. 46).

If we focus on the totality of verbal forms that he uses, if we refer to the Albanologe Wilfried Fiedler, we find in Kristoforidhi's work three types of verbal forms and combinations thereof:

1. The form identifiable through endings, ie. synthetic form.

2. Analytical form, formed by a synthetic form of an auxiliary verb and a form or several uncompleted forms.

3. Analytical forms, which are formed at least by a particle and a form of type 1 or 2 .

With regard to the first type there is no difference. Differences arise only by the fact that the respective author recognizes as forming-form the various combinations of auxiliary verbs with unfinished elements as well as the various particles (Fiedler, 2002, p. 36).

In addition to verbal forms used in this chapter, of special interest is the treatment of mood, tense and the diathesis (active and passive voice) of the verb. Kristoforidhi distinguishes the following moods of verbs: indicative, subjunctive, optative, imperative and participle. With the exception of the participle, which is no longer treated accordingly, the other moods match the today's lingual thinking. The merit of the author for a long time, just as later treated by S. Frashëri, is that he does not treat the admirative and conditional as separate moods, but presents those as respective tense forms of indicative mood (conditional and admirative) and subjunctive mood (admirative) of the verb (Karapinjalli, Stringa, 2002, p. 217).

The problem of recognition or non-recognition of these separate moods has been and remains the subject of discussion even today in Albanian linguistics. Referring to Kristoforidhi, various linguists have expressed different opinions regarding the problem in question, however, the most recent linguistic opinion is closer to Kristoforidhi's opinion for not recognizing the conditional mood as a separate mood (Karapinjalli, Stringa, 2002, p. 217).

Inclusion of conditional forms in the indicative mood, apparently, was made by Kristoforidhi, given the same forms that they have (Compare: the past future tense of indicative mood do të punoja and the past perfect tense of indicative mood do të kisha punuar, with the present tense of the conditional mood do të punoja and the perfect tense of the 
conditional mood do të kisha punuar, as well as by modal meaning of the feasibility of both tenses of the future. Therefore, the author is vindicated for treating similar forms in a single mood and not in two different moods (Karapinjalli, Stringa, 2002, f. 217-218).

Inclusion of tenses forms of admirative mood in the indicative mood was done by virtue of the modal meaning of the authentication which is the same for both moods, while the inclusion of tenses forms of admirative mood, even in the subjunctive mood, is done given the same grammatical form.

Regarding the grammatical category of tense we should point out the large number of tenses forms of the indicative and subjunctive moods. Just mentioning here 6 future tenses of admirative mood (the author includes these tenses in the optative mood): do të kërkuakam (sudden present tense), do të kërkuekësha (sudden imperfect tense), do të pasëkam kërkuarë (sudden perfect tense), do të pasëkësha kërkuarë (sudden pluperfect tense), do të pasëkam pasë kërkuarë (sudden perfect progressive tense) dhe do të pasëkësha pasë kërkuarë (sudden pluperfect progressive tense).

Any of these forms of admirative mood and, precisely, the form of the type do të kërkuakam appears even nowadays, although in a limited use. This verbal form, as also noted by $E$. Lafe, is an linguistic fact of Albanian language and has place in grammar (Karapinjalli, Stringa, 2002, p. 218).

We believe that Kristororidhi must have encountered other forms of admirative mood in the linguistic reality of the time, which are considered by Sh. Demiraj as analogical and irregular formations. A linguist as Kristoforidhi, who knew Albanian in its wealth of vocabulary and grammatical forms as hardly anybody, can not invent non-existent forms. Let us not forget that $\mathrm{S}$. Frashëri also used later in his grammar some of these verb forms of admirative mood (Karapinjalli, Stringa, 2002, p. 219).

Among his valuable contributions in this part of his Grammar we can mention the distinction of the present tense and the imperfect of indicative mood in indefinite and definite tense (kërkoj, kërkoja) and (po kërkoj, po kërkoja). He adds therein that the definite meaning of these two tenses can be also expressed with analytical forms such as jam duke kërkuar, isha duke kërkuar. (He calls these periphrastic forms respectively "present emphatic" or " imperfect emphatic"). This classification made by Kristoforidhi is fully supported by the linguists as M. Karapinjalli and R. Stringa agreeing with the recent verb division of indicative mood (but also of admirative mood) based on specific grammatical forms, as well as their respective meanings, properly considering him as the first linguist who has pointed out this phenomenon of Albanian language (Karapinjalli, Stringa, 2002, p. 219).

As also noted earlier, Kristoforidhi distinguishes the verbal forms that express an unexpected or sudden action. The same thing is also mentioned by Dozoni (Çeliku, 2009, p. 121), but Kristoforidhi has systematically treated these verb forms, now treated as specific forms called admirative mood. Kristoforidhi treats them more widely than they are treated today in the subjunctive and indicative mood and in the future tense, also citing forms wich were and still are not in use (Çeliku, 2009, p. 121).

Regarding the tenses of the indicative mood, whether for active and passive conjugation, Kristoforidhi has been rightly recognized the following forms: present and imperfect undefinite tense (punoj, punoja), present and imperfect definite tense (po punoj, po punoja), present and imperfect continous tense, emphatic, according to the author (jam duke punuar, isha duke punuar) (Karapinjalli, Stringa, 2002, p. 219).

He presents the following indicative forms: kërkuakam (present), kërkuakësham (imperfect), pasëkam kërkuarë (perfect), pasëkësham kërkuarë ( Subjuctive, past perfect), pasëkam pasë kërkuarë (second conjuction), pasëkësham pasë kërkuarë (past perfect).

He presents the following future forms: do të kërkuakam (future), do të kërkuakëshe (imperfect), do të pasëkam këkuarë (perfect), do të pasëkëshe kërkuarë ( future perfect), do të pasëkam pasë kërkuarë (second conjuction ), do të pasëkëshe pasë kërkuarë ( future perfect),

He presents the following subjunctive forms: të kërkuakam (present), të kërkuakësha (imperfect), të pasëkam kërkuarë (perfect), të pasëkëshe kërkuarë (subjuctive, perfect), të pasëkam pasë kërkuarë (subjuctive past perfect), të pasëkëshe pasë kërkuarë (subjuctive past perfect).

Regarding the optative mood, the author presents only the present tense (he considers this as the future tense), eg. kërkofsha and he does not recognize the imperfect tense. Apparently, the author considers the present as the future, given the meaning of the future that the optative present has. The rejection of the optative imperfect tense by Kristoforidhi, according to Karapinjall and Stringa, should be explained by its very rare use to express desire of the past actions (Karapinjalli, Stringa, 2002, p. 219).

Kristoforidhi does not recognize any tense for the imperative mood. In the imerative conjuagtion, he presents only the second person singular and plural. Various researchers have raised a question, regarding the treatment of the imperative mood by Kristoforidhi, which necessarily requires an accurate and well argued answer. 
Does Kristoforidhi devise admirative forms that have not been appeared ever before in Albanian? A response on this question is provided by the researcher Remzi Përnaska who, following an extensive research about this phenomenon, states: "I hasten to give my answer: No, Our distinguished linguist has not devised any form of admirative mood presented in his Grammar. Because: to better understand this, the shortest route is on the one hand, to understand the linguistic opinion of Kristoforidhi, and we should not observe only the admirative mood in this respect, but it should be observed the whole verbal system presented by hte author, and further, should be observed the whole Grammar and his deeds and, on the other hand, we should confront the forms that he presents not only our linguistic sense, but, and this is the foremost, the data of Albanian language itself" (Përnaska, 2002, p. 93).

First of all it would be appropriate to see what Kristoforidhi himself states about admirative mood based on his verbal opinion: He does not call it a mood but a tense: "The siple tenses of Albanian language are as follows: present tense, imperfect tense, sudden present tense, sudden imperfect tense and simple perfect tense.... Whereas the moods are: indicative, subjunctive, imperative, causative and participle... (Përnaska, 2002, p. 93-94).

The first who noticed that Albanian language has admirative mood is Ogyst Dozoni, who determines thus the two forms: the present tense and the imperfect tense: "These two tenses have a very special meaning such as awe, admiration, surprise, sometimes ironically..." (Përnaska, 2002, p. 94) and there he adds:" Kristoforidhi marks those with unexpected sudden epithet".

Indeed, Kristoforidhi determines thereby the grammatical sense of admirative mood:

"The sudden present tense indicates that the subject is already available without recognizing it, eg.: fjetëkam= sleep without knowing... . The sudden imperfect the subject is already available without recognizing it, as long as it was done, or was getting done something: ex.: fjetkëshe = I slept without knowing" (Përnaska, 2002, p. 94).

According to Përnaska, it should be noted that the edge of Kristoforidhi is neither admirative of Dozon, nor admirative of Sotir Peci the one that we still use today. He uses the edge unexpected which is closer to the edge of Sami Frashëri who considers the admirative forms as sudden. As it is seen, along with Sami we better understand the grammatical sense of admirative mood. This issue constitutes the Achilles' heel of the grammatical sense of admirative mood (Përnaska, 2002, p. 94).

In the system of verbal forms provided by Kristoforidhi, according to the linguist R. Përnaska it is noted a "symmetry", or as it can be called by some other linguists, symmetry found elsewhere in this Grammar. However, regarding this he would prefer to speak of a "linguistic architectony" present in this Grammar, architectony that appears quite clear in the admirative forms listed by him. Moreover, continues his idea the researcher, architectonic system of Kristoforidhi is not far in spirit from that of Gustav Gijomi. Kristoforidhi exclude from the architectony of simple tenses the simple perfect, from the compound tenses . (Përnaska, 2002, p. 95).

Emil Lafe, one of the best connoisseurs not only of admirative mood problems of Kristoforidhi, but also admirative mood in itself, formulates in this way his position: "The four other forms (R.P. të pasëkam pasë, të pasëkeshe pasë pasë, do të pasëkam pasë pasë, do të paskëshe pasë pasë of Kristoforidhi) have never been recorded and heard anywhere. Are nothing but inventions of Kristoforidhi, who, considering the admirative forms as variants of indicative and subjunctive, devised for each form of these two moods a respective admirative, regardless of use" (Përnaska, 2002, p. 95).

Meanwhile, the linguist Pernaska considers the Lafe's formulation as slightly accelerated regarding these forms which "...they have never been recorded and heard anywhere, are nothing but inventions of Kristoforidhi..." According to him, the same as the over-compound forms of indicative and subjunctive, these forms are "rarely" used, because certain conditions of an order in the past are necessary, mainly in the compound sentence or in the passive voice (it is not occassional the fact that Kristoforidhi adds them the adjective e përparme (front)). Therefore, it is not the form which is "rare", but the scope in which it is used. The linguistic sense of one or another linguist for one or another system of forms is not a decisive argument. Inventions of Kristoforidhi are also considered other forms, for which "linguistic sense" of one or another author has been decided to be kept on their grammar or should not be written at all and kept as non-existent. Therefore, the last author after Kristoforidhi and Sami who writes for the admirative form of the present tense (do të hapkësha) and past tense (do të paskësha hapur) of the conditional mood, is Gjergj Pekmezi (Përnaska, 2002, p. 96).

On the other hand, Emil Lafe also acknowledges the fact that "...this form is possible, from the standpoint of the language system, because past perfect tense of "subjunctive-admirative" të paskësha vajtur is linked to do të kem vajtur, which is fundamental and is used in the language. Further, he continues his opinion in this way: "Obviously, reasonings are made by immanentism of the system, whereas the results by use, by "reality" (Përnaska, 2002, p. 96). And it is observed even better on the reasoning made to say that the perfect tense of the conditional-admirative, pointed out by Kristoforidhi, is not in use to the same extent as the perfect tense of subjunctive-admirative të paskam vajtur which is in 
its foundation (Përnaska, 2002, p. 96). Therefore, according to Lafe we have this impossible double composition: do (të paskam vajtur). And here is how he supports his opinion:
Do të vete
do të vajtkam
Do të veja
do të vajtkësha
Do të kem vajtur
do (të paskam vajtur)
Do të kisha vajtur
do të paskësha vajtur

Given this line of reasoning, he further follows his opinion, we go to the conclusion that "Kristoforidhi has pointed out admirative forms for four subjunctive tenses: të pasëkam, të paskeshe, të pasëkam pasë, të paskeshe pasë, at a time when Sami Frashëri rebuked Kristoforidhi keeping only the imperfect and past perfect tense. Apparently, the present tense is not used in this way and the past tense is not used today" (Përnaska, 2002, p. 96).

Before we close this chapter on verbs, we consider reasonable to briefly mention his opinion for the diathesis of the verbs (active and passive voice). In the Grammar of Kristoforidhi is not mentioned the term "diathesis", but it comes to the active and the passive voice of the verbs. The author uses the term "passive" in the sense of "passive voive" In this Grammar he mentions the term "medial", he even provides the conjugation of two verbs: gjen (which is not medial) and duket.

As it is seen, according to Kristoforidhi, the verbs in terms of diathesis are grouped into three groups: active verb, passive verb, medial verb (Karapinjalli, Stringa, 2002, p. 220).

Regarding the verbal chapter, we present another note that refers to admirative form, for which Dozon points out that "Kristoforidhi determines them with the epithet aprosdokétés "anticipated, unexpected". This last note of Dozon makes it even more clear the fact that in 1874 Kristoforidhi either had completed, or was compiling his grammar, where he widely describes the admirative forms, calling them aprosdokétés (Demiraj, 2002 p. 44).

In this short presentation we tried to reflect in general some linguistic approaches which appeared significant to us and which are present even to this day.

However, at this point it is worth to express the position of the linguist Sh. Demiraj which states: "We can affirm that Kristoforidhi with his good linguistic preparation managed to distinguish clearly that in Albanian language there are also special verb forms, through which it is expressed the attitude of the speaker (amazement dissent, irony, etc.) to an unexpected and unusual action. As it is already known, in this case we are dealing with characteristic Albanian verbal forms which are formed as a result of an internal development of the Albanian language" (Demiraj, 2002 p. 47).

Actually, we should also record that some of the approaches that are reflected in the Grammar of Kristoforidhi have continued and have become also part of subsequent authors and grammars.

In conclusion we wish to emphasize that the "Grammar of the Albanian language" of Kristoforidhi is a rich source of information not only for grammarians, but also for dialectologists, historians of language, etymologists, etc., who in the future should also be referred to his work which constitutes an invaluable treasure of the Albanian language.

\section{Concusions}

"Grammar of the Albanian language" of Kostandin Kristoforidhi constitutes one of the most important works for Kristoforidhi and in meantime most valuable for the Albanian linguistics. If we compare the Grammar of Kristoforidhi with the present linguistic opinion it results that in general we have a line of approaches associated with various phenomena in the grammatical aspect in their most significant part. This is evident in the same order of parts of speech, in their almost equal number, as well as in their respective categories. In this text, chapter by chapter verb constitutes one of the most extensive and most prominent chapters even by today's linguists.

If we focus on the linguistic treatment of Kristoforidhi on the lexicon and grammatical category of the verb, some innovation and valuable approaches result relating the Albanian language the Albanian and Grammatology. His values and contributions appear at these aspects:

- Kristoforidhi distinguishes the following verb moods: indicative, subjunctive, causative, imperative and participle. With the exception of the participle, which is no longer considered accordingly, the other moods comply with the last linguistic opinion.

- The merit of the author since long time ago just as later treated by S. Frashëri is that he does not treat the admirative and conditional as separate moods, but presents those as respective tense forms of indicative mood (conditional and admirative) and subjunctive mood (admirative) of the verb. The problem of recognition or non-recognition of these separate moods has been and remains the subject of discussion even today in Albanian linguistics. Referring to Kristoforidhi various linguists have expressed different opinions regarding the 
problem in question, however, the most recent linguistic opinion is closer to Kristoforidhi's opinion for not recognizing the conditional mood as a separate mood.

- It is distinguished in Grammar the prsent tense and the imperfect tense of the indicative mood in definite and indefinite tenses (kërkoj, kërkoja) and (po kërkoj, po kërkoja).

For the prsent tense and the imperfect tense of the indicative mood, either for the active and for the passive voice, Kristoforidhi has been distinguished the following verb tenses: present and imperfect undefinite tense (punoj, punoja), present and imperfect definite tense (po punoj, po punoja), present and imperfect continous tense, emphatic, according to the author (jam duke punuar, isha duke punuar).

- An important and highly controversial issue related to admirative forms reflected by Kristoforidhi. He determines thereby the grammatical sense of admirative mood: "The sudden present tense indicates that the subject is already available without recognizing it, eg.: fjetëkam= sleep without knowing... . The sudden imperfect the subject is already available without recognizing it, as long as it was done, or was getting done something: ex.: fjetkëshe $=$ I slept without knowing.

Based on linguistic approaches that permeate this chapter and the Grammar itself as a whole, it must be said that Kristoforidhi and his linguistic concepts have been and will remain a very valuable stone for the Albanian linguistics.

\section{References}

Çeliku, Mehmet, Standard Albanian Issues, Tirana, 2009.

Demiraj, Shaban, About Grammar of Kristoforidhi, in "Summary of studies for Kristoforidhi", Universiteti "Aleksandër Xhuvani", Scientific research center, sector of Albanology-Balkanology , Elbasan, 2002.

Fiedler, Wilfried, Kristoforidhi concepts on the structure of phonetics and morphology of Albanian language, in "Summary of studies for Kristoforidhi", Universiteti "Aleksandër Xhuvani”, Scientific research center, sector of Albanology-Balkanology , Elbasan, 2002.

Karapinjalli, Mustafa; Stringa, Ruzhdi, Grammar of Kristoforidhi in today's view, in "Summary of studies for Kristoforidhi", Universiteti "Aleksandër Xhuvani", Scientific research center, sector of Albanology-Balkanology , Elbasan, 2002.

Përnaska, Remzi, Does Kristoforidhi devise forms of admirative mood? in "Summary of studies for Kristoforidhi", Universiteti "Aleksandër Xhuvani", Scientific research center, sector of Albanology-Balkanology , Elbasan, 2002. 